Tropical Journal of Pharmaceutical Research March 2021; 20 (3): 537-541

ISSN: $1596-5996$ (print); 1596-9827 (electronic)

(C) Pharmacotherapy Group, Faculty of Pharmacy, University of Benin, Benin City, 300001 Nigeria.

\title{
Effect of dexmedetomidine on AKT/ERK signaling pathway and EMT-related proteins in high glucose-induced apoptosis in human renal tubular epithelial cells
}

\author{
Shuhua Wei ${ }^{1 *}$, Jiang $\mathrm{Wu}^{2}$, Yubo Liu ${ }^{1}$, Xiang $\mathrm{He}^{1}$ \\ ${ }^{1}$ Department of Anesthesiology, Jiangxi General Hospital of Armed Police Force, Nanchang City, ${ }^{2}$ Department of \\ Anesthesiology, 909 Hospital of Joint Logistics Support Force, Zhangzhou City, China
}

*For correspondence: Email: fctyh9@163.com

Sent for review: 17 December 2020

Revised accepted: 7 March 2021

\begin{abstract}
Purpose: To study the effect of dexmedetomidine (Dex) on AKTERK signaling pathway and EMTrelated proteins in high glucose-induced apoptosis in human kidney tubular epithelial cells.

Methods: HK-2 cells were assigned to control, high-glucose and Dex groups. Levels of ROS were determined using live cell station. Flow cytometry was used to measure cell apoptosis and cell cycle while Western blot was applied to assay levels of PI3K, Akt, $p-A k t$, ERK and $p$-ERK.

Results: The ROS concentrations were markedly reduced in Dex group, relative to high glucose group $(p<0.05)$. Apoptosis was reduced in Dex group, relative to high glucose group, while P13K protein levels were significantly lower in high glucose and Dex groups than their corresponding control levels. In the high glucose-treated cells, AKT protein expression was downregulated, relative to control group, and $p$-AKT expression was markedly reduced in Dex group $(p<0.05)$. Protein expressions of ERK and $p$-ERK in high glucose group were lower than control values, but were significantly accentuated in Dex group, relative to high glucose group $(p<0.05)$.

Conclusion: Dex mitigates high glucose-induced apoptosis of HK-2 cells, increases the proportion of cells in $\mathrm{G} 1$ phase, and reduces their EMT via a mechanism related to regulation of AKTERK signaling pathway-associated proteins. AKTERK signaling pathway-associated proteins provide insights into the development of drugs for the treatment of diabetic nephropathy.
\end{abstract}

Keywords: Dexmedetomidine, High glucose, Human renal tubular epithelial cells, AKTERK signaling pathway, EMT-related proteins

\begin{abstract}
This is an Open Access article that uses a fund-ing model which does not charge readers or their institutions for access and distributed under the terms of the Creative Commons Attribution License (http://creativecommons.org/licenses/by/4.0) and the Budapest Open Access Initiative (http://www.budapestopenaccessinitiative.org/read), which permit unrestricted use, distribution, and reproduction in any medium, provided the original work is properly credited.

Tropical Journal of Pharmaceutical Research is indexed by Science Citation Index (SciSearch), Scopus, International Pharmaceutical Abstract, Chemical Abstracts, Embase, Index Copernicus, EBSCO, African Index Medicus, JournalSeek, Journal Citation Reports/Science Edition, Directory of Open Access Journals (DOAJ), African Journal Online, Bioline International, Open-J-Gate and Pharmacy Abstracts
\end{abstract}

\section{INTRODUCTION}

Diabetic nephropathy (DN) is a chronic metabolic disorder caused by deficiency in insulin secretion and/or dysfunction in insulin action. It occurs frequently in diabetic patients, and it is a serious microvascular disease that can lead to kidney failure and end-stage renal disease [1]. Recent studies have found that the incidence of DN is increasing year by year, thereby seriously endangering the life and health of patients [2]. At present, the pathogenesis of DN is not completely clear. However, it has been reported that the occurrence of $\mathrm{DN}$ is closely related to 
renal interstitial fibrosis caused by renal tubular epithelial mesenchymal transition (EMT) [3]. Therefore, it is important to study etiology of DN and the associated mechanisms, so as to mitigate the disease and maintain normal renal function. Dexmedetomidine (Dex) is a highly selective $\alpha 2$-receptor agonist with sedative, analgesic and respiration-enhancing effects [4]. Previous studies have shown that Dex protects the heart, liver, kidney and nerves, and reduces oxidative stress injury and ischemia/reperfusion injury [5]. Although there are many studies on the protective effect of Dex on acute kidney injury and renal ischemia reperfusion, there are limited reports on the effect of Dex on DN [6]. The purpose of research was to ascertain the influence of Dex on HK-2 cells, as well as the underlying mechanisms.

\section{EXPERIMENTAL}

\section{Materials}

Human renal cortex proximal convoluted tubule epithelial cells (HK-2 cells) were provided by Wuhan Yipu Biotechnology Co. Ltd.

\section{HK-2 cell culture}

The cells were cultured in DMEM/F12 spiked with $10 \%$ FBS, and the culture medium was placed in a $5 \% \mathrm{CO}_{2}$ incubator at $37^{\circ} \mathrm{C}$. When the cells reached $80 \%$ confluence, they were digested with trypsin and EDTA for $1 \mathrm{~min}$, and centrifuged at $1000 \mathrm{rpm}$ for $5 \mathrm{~min}$. Then, the cells were mixed with DMEM/F12 and sub-cultured at $1: 4$ ratio.

\section{Cell grouping and transfection}

The cells were assigned to control, high-glucose and Dex groups. Cells at logarithmic phase were digested with trypsin. The cells were plated in a 6 -well cell plate at a concentration of $1 \times 10^{6}$ cells per well, and the medium was changed at $80 \%$ confluence. Control group cells were maintained in $5 \mathrm{mM}$ glucose medium, while cells in the highglucose group were maintained in a medium with glucose concentration of $30 \mathrm{mM}$. Cells in the Dex group were cultured in $30 \mathrm{mM}$ glucose medium and Dex concentration of $1 \mu \mathrm{mol} / \mathrm{L}$. The three groups were placed in an incubator with $5 \%$ carbon dioxide at $37{ }^{\circ} \mathrm{C}$ for $24 \mathrm{~h}$, prior to use in subsequent studies.

\section{Examination of cell morphology}

After $24 \mathrm{~h}$ of high-glucose treatment, the 3 groups of HK-2 cells were made into cell smears, and their morphologies were examined under a light microscope.

\section{Determination of ROS (superoxide dismutase) levels}

After 24-h exposure to high glucose concentration, $100 \mu \mathrm{L}$ of culture medium containing fluorescent probe working solution was added, followed by incubation for $20 \mathrm{~min}$. Thereafter, the cells were washed thrice with DMEM/F12, followed by addition of $100 \mu \mathrm{L}$ of PBS buffer to each well. The fluorescence intensity of each well was measured at $480 \mathrm{~nm}$ and $525 \mathrm{~nm}$ at a live cell station.

\section{Determination of apoptosis}

Following 24-h exposure to high glucose induction, the HK-2 cells were placed in PBS buffer, spun for $5 \mathrm{~min}$ at $1500 \mathrm{rpm}$, and resuspended in $500 \mu \mathrm{L}$ of $1 \mathrm{x}$ binding buffer. Then, the cells were treated with Annexin V-FITC and $\mathrm{PI}$ dye (5 $\mu \mathrm{L}$ each), thoroughly mixed, and incubated away from light for $15 \mathrm{~min}$. Cell apoptosis was analyzed flow cytometrically using BD flow cytometry software.

\section{Determination of cell cycle}

After $24 \mathrm{~h}$ of high-glucose concentration treatment, the HK-2 cells were rinsed in PBS buffer, spun at $15 \mathrm{rpm}$ for $5 \mathrm{~min}$, resuspended in PBS, spun for $5 \mathrm{~min}$ at $1500 \mathrm{rpm}$, and stored at $20{ }^{\circ} \mathrm{C}$ for $24 \mathrm{~h}$, followed by centrifugation at 800 $\mathrm{g}$ for $5 \mathrm{~min}$, and washing once with PBS buffer. Then, $500 \mu \mathrm{L}$ of propidium iodide/RNase was added and incubated on ice for 15 to $30 \mathrm{~min}$. Cell cycle was analyzed using flow cytometry, and analyzed with BD flow cytometry software.

\section{Immunoblot assay}

After 24-h high glucose treatment, total protein was extracted from the 3 groups of HK-2 cells using protein extraction kit, and total protein contents were measured with BCA kit. The protein expressions of $\mathrm{PI} 3 \mathrm{~K}$, Akt and their phosphorylated derivatives were determined with Western blotting, with GAPDH as reference gene. The images were photographed and analyzed with Tanon600 Image Analysis System.

\section{Statistics}

Results are expressed as mean \pm SD. The SPSS 20.0 package was applied for analyzing data. Inter-group comparison was carried out with $t$ test. Counting data are expressed as percentage, and $x^{2}$ test was used for inter-group 
comparison. Values of $p<0.05$ indicated statistically significant differences.

\section{RESULTS}

\section{Morphology of cells}

Cell morphology in the control group reflected the structure of typical, cobblestone-like cube epithelial cells arranged closely together. There were alterations in cell morphology of highglucose group, with increases in cell volume and decreases in cell density. Cell morphology in the Dex group was good, and cell density was markedly raised, higher than that in high-glucose cells, but was lower, relative to control, as shown in Figure 1.
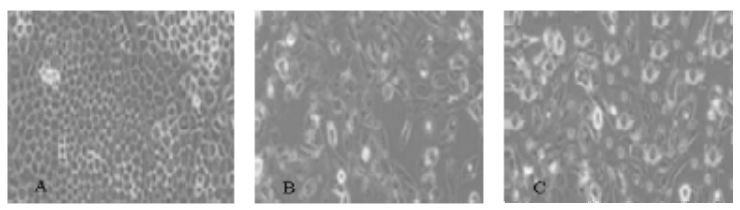

Figure 1: Morphological analysis of cells in each group. A: Morphological images of control cells; B: morphological images of high glucose-treated cells; C: morphological images of cells in the Dex group

\section{ROS levels in cells}

As shown in Table 1, ROS levels in high glucoseexposed cells were markedly higher than control value, while ROS levels were decreased in Dexexposed cells, relative to high glucose group.

Table 1: ROS level in each group of cells

\begin{tabular}{lc}
\hline Group & ROS \\
\hline Control & $2454.62 \pm 256.89$ \\
High glucose & $3745.26 \pm 346.29 a$ \\
Dex & $2516.35 \pm 321.25 b$ \\
\hline${ }^{a} P<0.05$, compared with control; ${ }^{b} p<0.05$, vs high \\
glucose group
\end{tabular}

\section{Cell apoptosis}

Table 2 shows that percentage of apoptosis in cells was markedly raised in high glucoseexposed cells, relative to control cells, but there was lower degree of apoptosis in Dex group than in the high glucose group $(p<0.05)$.

Table 2: Apoptosis levels in the cells

\begin{tabular}{lc}
\hline Group & Apoptosis (\%) \\
\hline Control & $82.41 \pm 16.38$ \\
High glucose & $115.68 \pm 20.16 \mathrm{a}$ \\
Dex & $83.64 \pm 18.52 \mathrm{~b}$ \\
\hline${ }^{\mathrm{a} P}<0.05$, compared with control; ${ }^{\mathrm{b}} p<0.05$, compared \\
with the high glucose group
\end{tabular}

\section{Effect of treatments on cell cycle distribution}

There was reduced number of cells in G1 phase in high glucose group, relative to control, while G1 phase cells were higher in Dex group than in high glucose-treated cells $(p<0.05)$. These results are shown in Table 3.

Table 3: Cell cycle distribution in the cells

\begin{tabular}{lccc}
\hline Group & G1 phase & G2 phase & S phase \\
\hline Control & $77.49 \pm 5.12$ & $5.95 \pm 3.16$ & $16.56 \pm 6.81$ \\
High & $71.44 \pm 5.06^{\mathrm{a}}$ & $8.00 \pm 3.85$ & $20.56 \pm 6.37$ \\
glucose & $78.56 \pm 5.12^{\mathrm{b}}$ & $5.68 \pm 3.16$ & $15.76 \pm 6.85$ \\
Dex & 11.330 & 2.930 & 2.960 \\
$F$ & 0.001 & 0.061 & 0.059 \\
$P$-value & \multicolumn{2}{l}{${ }^{\mathrm{a}} \mathrm{P}<0.05$, versus } & control; ${ }^{\mathrm{b}} p<$ \\
&
\end{tabular}

\section{Protein expression levels of AKTERK signaling pathway}

The expression levels of PI3K protein in the high glucose and Dex groups were markedly decreased, relative to control, and PI3K protein level in Dex group was significantly higher than that in high glucose-exposed cells. Compared to control, AKT protein was reduced in high glucose group, but the expression of $\mathrm{p}$-AKT protein in Dex-treated cells was markedly lower than control value. However, AKT protein levels in Dex and control groups were comparable, as was the case in p-AKT expressions in high glucose and control groups. These results are shown in Table 4.

Table 4: Quantified expressions of AKT/ERK signaling pathway-related proteins

\begin{tabular}{lccc}
\hline Group & PI3K & AKP & p-AKP \\
\hline Control & $1.02 \pm 0.05$ & $1.01 \pm 0.04$ & $1.02 \pm 0.03$ \\
High & $0.35 \pm 0.02 \mathrm{a}$ & $0.59 \pm 0.03 \mathrm{a}$ & $1.23 \pm 0.16 \mathrm{a}$ \\
glucose & $0.68 \pm 0.03 \mathrm{ab}$ & $0.94 \pm 0.03 \mathrm{~b}$ & $1.05 \pm 0.05 \mathrm{~b}$ \\
Dex & &
\end{tabular}

\section{Levels of EMT-related proteins}

As presented in Table 5, ERK and p-ERK were reduced in high glucose-exposed cells, relative to control values, while their expression levels were markedly upregulated in Dex group, relative to high glucose-exposed cells.

Table 5: Quantified expression levels of EMT-related proteins in the cells

\begin{tabular}{lcc}
\hline Group & ERK & p-ERK \\
\hline Control & $1.01 \pm 0.05$ & $1.02 \pm 0.04$ \\
High glucose & $1.45 \pm 0.11 \mathrm{a}$ & $1.67 \pm 0.21 \mathrm{a}$ \\
Dex & $1.05 \pm 0.03 \mathrm{~b}$ & $0.86 \pm 0.06 \mathrm{~b}$ \\
\hline
\end{tabular}




\section{DISCUSSION}

With improvements in standard of living and increases in the aging population, the prevalence of diabetes has continued to increase year by year, thereby constituting a serious public health problem worldwide [7]. It is known that DN is a major complication in the diabetic state. Previous studies have shown that DN cannot be effectively suppressed even if blood sugar and blood pressure are strictly controlled in diabetic patients. Indeed, about $33 \%$ of diabetic patients still end up with end-stage renal disease [8]. Therefore, early diagnosis of diabetes and early treatment are of great significance for delaying the development of DN and improving life quality amongst diabetics.

The binding of Dex to its receptor inhibits the release of norepinephrine caused by excessive stress response, a mechanism through which Dex protects the kidney. Dexmedetomidine (Dex) also decreases the concentration of catecholamine in the body, inhibits the secretion of antidiuretic hormone, maintains the stability of physiological hemodynamics, and ensures renal blood perfusion [9]. The results of this study showed that there were changes in cell morphology of high-glucose group, with increase in cell volume and decrease in cell density. The cell morphology of the Dex group was good, and cell density was significantly higher than that in cells treated with high-glucose, but lower than control value, while ROS levels in cells exposed to high glucose were markedly higher than control values. Moreover, ROS levels were lower in Dex-treated cells than in cells exposed to high glucose. These findings suggest that Dex may alleviate glucose-induced lesions and oxidative stress in HK-2 cells. This is similar to the finding reported earlier by Elyazed et al [10].

Previous investigations showed that renal tubular EMT is associated with renal interstitial fibrosis, and excessive deposition of ECM protein in glomeruli and renal tubules lead to glomerulosclerosis and interstitial fibrosis, which ultimately affect renal function in patients [11]. The protein expressions of ERK and p-ERK in cells exposed to high glucose were markedly lower than those in control cells, while their expressions in Dex cells were upregulated, relative to those in cells cultured in high-glucose medium. This suggests the induction of EMT in HK-2 cells by high glucose, while Dex inhibited the EMT-associated events and protected renal tubular epithelial cells.

If diabetic patients are in a state of high blood glucose concentration for a long time, ROS levels increase, and the resultant oxidative stress is associated with the pathogenesis of EMT and renal fibrosis [12]. Chen et al [13] showed that high glucose levels promoted cell differentiation and induced cell fibrotic changes by reducing the $\mathrm{G} 1$ phase ratio of mouse mesangial cells. In this study, the apoptosis of cells in the cells exposed to high glucose was higher than apoptosis in control cells, while apoptosis was markedly decreased in Dex cells, relative to high glucosetreated cells. The population of cells in G1 phase was decreased in high glucose-treated cells, when compared with control cells, while G1 phase cells were significantly higher in number in the Dex group than in the high glucose group. This indicates that Dex delayed EMT of renal tubular epithelial cells through suppression of oxidative changes and increase in population of G1 cells. A similar result was reported in an earlier study by Jafari et al [14].

The AKTERK signaling pathway is an important intracellular signal transcription route which participates in several of biological events such as cell proliferation, differentiation and apoptosis. Abnormal activation of PI3K induces phosphorylation of AKT protein, while p-AKT promotes phosphorylation of various downstream enzymes and transcription factors, thereby regulating cell function. Studies by Spirina et al [15] revealed that the AKTERK signaling pathway is closely related to the etiologies of a variety of fibrotic diseases. In this research, PI3K levels in high-glucose and Dex groups were markedly reduced, relative to control value, and PI3K protein level was markedly higher in the Dex-treated cells than in the high glucoseexposed cells, while AKT protein expression was lower in high glucose-treated cells, relative to control group. However, protein expression of $p$ AKT was markedly downregulated in Dex-treated cells, relative to control. Thus, Dex may effectively slow down high glucose-induced apoptosis and EMT of HK-2 cells through regulation of the AKTERK signaling pathway.

\section{CONCLUSION}

This study has demonstrated that Dex alleviated high glucose-induced apoptosis of HK-2 cells, increased the population of $\mathrm{G} 1$ phase cells, and reduced the EMT of HK-2 cells via a mechanism most likely related to regulation of AKTERK signaling pathway-associated proteins. Thus, the AKTERK signaling pathway-associated proteins may provide insights into development of drugs for the treatment of diabetic nephropathy.

Trop J Pharm Res, March 2021; 20(3): 540 


\section{DECLARATIONS}

\section{Conflict of interest}

No conflict of interest is associated with this work.

\section{Contribution of authors}

We declare that this work was performed by the authors named in this article and all liabilities pertaining to claims relating to the content of this article will be borne by the authors. Shuhua Wei designed the study, supervised the data collection, and analyzed the data. Jiang $\mathrm{Wu}$ interpreted the data and prepared the manuscript for publication. Yubo Liu and Xiang $\mathrm{He}$ supervised the data collection, analyzed the data and reviewed the draft of the manuscript. Shuhua Wei and Jiang Wu contributed equally to this work as co-first authors.

\section{Open Access}

This is an Open Access article that uses a funding model which does not charge readers or their institutions for access and distributed under the terms of the Creative Commons Attribution License (http://creativecommons.org/licenses/by/ 4.0) and the Budapest Open Access Initiative (http://www.budapestopenaccessinitiative.org/rea d), which permit unrestricted use, distribution, and reproduction in any medium, provided the original work is properly credited.

\section{REFERENCES}

1. Dilip S, Pallab B, Kiran, Vinod T. Diabetic nephropathy: new insights into established therapeutic paradigms and novel molecular targets. Diabetes Res Clin Pract 2017; 128: $91-108$.

2. Luping Z, Wei $H$, Youhua $X$, Chenlin G, Ting Z, Man G, Yan L, Jingya $D$, Ludan $Q$, Zihao $X$, et al. Sweet taste receptors mediated ros-nlrp3 inflammasome signaling activation: implications for diabetic nephropathy. J Diabetes Res 2018; 2018: 1-15.

3. Noori A, Hamza A, Thia A, Khelod S. Natural antioxidants in the treatment and prevention of diabetic nephropathy; a potential approach that warrants clinical trials. Redox Rep 2017; 22(3): 99-118.

4. Lijun W, Haiyan L, Ligong Z, Gongming W, Mengyuan Z, Yonghui $Y$. Neuroprotection of dexmedetomidine against cerebral ischemia-reperfusion injury in rats: involved in inhibition of $n f-\kappa b$ and inflammation response. Biomol Ther (Seoul) 2017; 25(4): 383-389.

5. Masayuki S, Manami I, Tatsunori O, Ran O, Mayumi T, Katsuji O. Combined neuroprotective effects of propofol and dexmedetomidine on endoplasmic reticulum stressmediated apoptosis in sh-sy5y cells. Showa Uni J Med Sci 2017; 28(3): 219-231.

6. Nana S, Chikako S, Junko T, Toshio I, Katsuhisa S. Imidazoline 1 receptor activation preserves respiratory drive in spontaneously breathing newborn rats during dexmedetomidine administration. Aediatr Anaesth 2017; 27(5): 506-515.

7. Snehal NM, Jayesh BD, Sangita BK, Archana RJ. Attenuation of diabetic nephropathy in streptozotocininduced diabetic rats by Punica granatum Linn. leaves extract. J Tradit Complement Med 2017; 7(3): 273-280.

8. Seki N, Matsumoto T, Fukazawa M. Relationship between the brain natriuretic peptide (bnp) level and prognosis of diabetic nephropathy with microalbuminuria: a 7-year follow-up study. Horm Metab Res 2018; 50(5): 389-396.

9. Peng ZM, Jing $L$, Ping SH, Fei $T$. Protective effect of dexmedetomidine on endotoxin-induced acute lung injury in rats. Med Sci Monit 2018; 24: 4869-4875.

10. Elyazed MA, Mogahed M. Comparison of magnesium sulfate and dexmedetomidine as an adjuvant to $0.5 \%$ ropivacaine in infraclavicular brachial plexus block. Anesth Essays Res 2018; 12(1): 109-115.

11. Natsumi K, Toshiki M, Satoshi H, Tsubasa S, Kazuho O, Kensuke M, Kohei M, Daizo K. Long noncoding RNA NORAD regulates transforming growth factor- $\beta$ signaling and epithelial-to-mesenchymal transition-like phenotype. Cancer Sci 2018; 109(7): 2211-2220.

12. Li D, Tian B, Jin XS. Mir-630 inhibits epithelial-tomesenchymal transition (emt) by regulating the $w n t / \beta$ catenin pathway in gastric cancer cells. Oncol Res Featuring Preclin Clin Cancer Ther 2018; 27(1): 9-17.

13. Shaojun $C$, Junyi $X$, Yao S, Li H, Chengjun F, Zhan L, Haixin $H$, Yongqiang $L$. MicroRNA-145 suppresses epithelial to mesenchymal transition in pancreatic cancer cells by inhibiting TGF- $\beta$ signaling pathway. J Cancer 2020; 11(9): 2716-2723.

14. Reza J, Reza A, Reza F, Gholamreza $P$, Sanaz D, Mojgan $M$, Adeleh A, Abbas $R$, Nader T. Downregulation of inflammatory signaling pathways despite up-regulation of Toll-like receptors; the effects of corticosteroid therapy in brain-dead kidney donors, a double-blind, randomized, controlled trial. Mol Immunol 2018; 94: 36-44.

15. Liudmila VS, Irina VK, Evgeny AU, Alexey KG, Irina VK. Transcription factor brn-3 $\alpha$ and prostate cancer, relation with hormone receptors and akt/m-tor signaling pathway activation. Siberian J Oncol 2018; 17(1): 26-31. 